2001 98: $2887-2893$

doi:10.1182/blood.V98.10.2887

\title{
Direct evidence that leukemic cells present HLA-associated immunogenic peptides derived from the BCR-ABL b3a2 fusion protein
}

Richard E. Clark, I. Anthony Dodi, Seran C. Hill, Jennie R. Lill, Geraldine Aubert, Andrew R. Macintyre, Jose Rojas, Audrey Bourdon, Philip L. R. Bonner, Lihui Wang, Stephen E. Christmas, Paul J. Travers, Colin S. Creaser, Robert C. Rees and J. Alejandro Madrigal

Updated information and services can be found at: http://bloodjournal.hematologylibrary.org/cgi/content/full/98/10/2887

Articles on similar topics may be found in the following Blood collections: Immunotherapy (577 articles)

Plenary Papers (244 articles)

Neoplasia (4100 articles)

Information about reproducing this article in parts or in its entirety may be found online at: http://bloodjournal.hematologylibrary.org/misc/rights.dtl\#repub_requests

Information about ordering reprints may be found online at:

http://bloodjournal.hematologylibrary.org/misc/rights.dtl\#reprints

Information about subscriptions and ASH membership may be found online at: http://bloodjournal.hematologylibrary.org/subscriptions/index.dtl 


\section{Direct evidence that leukemic cells present HLA-associated immunogenic peptides derived from the BCR-ABL b3a2 fusion protein}

Richard E. Clark, I. Anthony Dodi, Seran C. Hill, Jennie R. Lill, Geraldine Aubert, Andrew R. Macintyre, Jose Rojas, Audrey Bourdon, Philip L. R. Bonner, Lihui Wang, Stephen E. Christmas, Paul J. Travers, Colin S. Creaser, Robert C. Rees, and J. Alejandro Madrigal

\begin{abstract}
The BCR-ABL oncogene is central in the pathogenesis of chronic myeloid leukemia (CML). Here, tandem nanospray mass spectrometry was used to demonstrate cell surface HLA-associated expression of the BCRABL peptide KQSSKALQR on class I-negative CML cells transfected with HLA-
\end{abstract}

\author{
$A^{*} 0301$, and on primary $C M L$ cells from \\ HLA-A3-positive patients. These patients \\ mounted a cytotoxic T-lymphocyte response \\ to KQSSKALQR that also killed autologous \\ CML cells, and tetramer staining demon- \\ strated the presence of circulating \\ KQSSKALQR-specific T cells. The findings
}

are the first demonstration that CML cells express HLA-associated leukemia-specific immunogenic peptides and provide a sound basis for immunization studies against BCRABL. (Blood. 2001;98:2887-2893)

๑๐ 2001 by The American Society of Hematology

\section{Introduction}

Chronic myeloid leukemia (CML) is a serious neoplastic disorder of the hematopoietic stem cell, characterized by an initial chronic phase of variable length, which commonly transforms to an incurable acute leukemia. Although an uncommon disease, CML has attracted a disproportionate amount of research attention, because the molecular genetics of the chronic phase are well understood and may represent a model for many other malignant conditions. The Philadelphia $(\mathrm{Ph})$ translocation that typifies almost all cases juxtaposes the $A B L$ gene on chromosome 9q34 to $B C R$ on chromosome 22q11. Although the genomic breakpoints on both chromosomes 9 and 22 may vary from patient to patient over several kilobases, they occur only in introns. ${ }^{1}$ The resulting $B C R-A B L$ messenger RNA (mRNA) transcript comprises a proximal $B C R$-derived portion ending with exon 2 or 3 (denoted by b2 or b3, respectively), fused to $A B L$ exons 2 to 11 (denoted by a2). ${ }^{2}$ Almost all Ph-positive CML patients express either b3a2 or b2a2 fusion transcripts, depending on whether exon b3 is included. When translated, b2a2 and b3a2 mRNA each generate a $210-\mathrm{kDa}$ BCR-ABL protein ( $\mathrm{p} 210)$, which is necessary and sufficient for leukemic transformation. ${ }^{3}$ The $B C R-A B L$ junction in b3a2 mRNA disrupts a triplet codon, producing a novel lysine $(\mathrm{K})$ at the junction in the $\mathrm{b} 3 \mathrm{a} 2 \mathrm{BCR}-\mathrm{ABL}$ protein product. A codon disruption also occurs at the b2a2 fusion junction (Asp altered to Glu), but in this case the novel amino acid may not be recognized as it is also present at the normal a1a2 junction.

Endogenous antigen is presented to the immune system by initial degradation to oligopeptides typically of 8 to 11 amino acids, which are assembled in the endoplasmic reticulum lumen into a stable complex with newly synthesized class I HLA $\alpha$ chain and $\beta-2$ microglobulin. This complex is then exported to the cell surface, for recognition by cytotoxic T-lymphocytes (CTLs).

From the Departments of Life Sciences and Chemistry and Physics, Nottingham Trent University, Nottingham, United Kingdom; Departments of Haematology and Immunology, University of Liverpool, Liverpool, United Kingdom; and The Anthony Nolan Research Institute, The Royal Free and University College Medical School, London, United Kingdom.

Submitted June 22, 2001; accepted July 16, 2001.

Supported by the Nottingham Trent University Research award (J.R.L.), the John and Lucille van Geest Foundation (S.C.H.), and the North West Cancer Research Fund.
Oligopeptides derived from the BCR-ABL junction are potential novel CML-specific antigens and may therefore elicit an immune response. Several class I HLA molecules have been reported to bind strongly to peptides spanning the BCR-ABL fusion junction. ${ }^{4-8}$ Bocchia et al ${ }^{4}$ identified BCR-ABL b3a2 junctional 9-mers that bound strongly to HLA-A3 and A11 (sequence KQSSKALQR) and B8 (sequence GFKQSSKAL). These peptides also elicited specific class I-restricted CTL activity. ${ }^{5}$ HLA-A2 is capable of binding a different b3a2 fusion peptide that is able to elicit CTL responses in healthy donors and CML patients. ${ }^{6}$ These data suggest that certain BCR-ABL junctional peptides may preferentially bind to certain HLA alleles.

BCR-ABL junctional peptides can induce in vitro CTL activity or $\mathrm{CD}^{+}$cell proliferative responses in healthy subjects. ${ }^{5,6,8-16}$ Antigen presenting cells (APCs) loaded with BCR-ABL junctional 9-mers will elicit specific class I-restricted CTL activity from autologous fresh peripheral blood mononuclear cells (PBMC)s. ${ }^{5,6}$ By using T-cell blasts pulsed with high concentrations of BCRABL peptide as APCs, we have recently reported that BCR-ABLspecific CTLs elicited from healthy subjects will kill CML cells in an HLA-restricted fashion, ${ }^{16}$ providing indirect evidence that CML cells may naturally express BCR-ABL junctional peptides. However, no evidence of BCR-ABL junctional peptides was seen among peptides eluted from HLA molecules on CML cells, ${ }^{17}$ although only HLA-A*0201 was studied. It is possible that the technique used in that work (high-performance liquid chromatography [HPLC]) may have been too insensitive to distinguish the low level of BCR-ABL peptides from among the "noise" of other extracted material. Furthermore, although tumor cell lysates have been shown to contain HLA-bound peptides that are recognized by antigen-specific CTLs, ${ }^{18-21}$ these experiments do not discriminate
R.E.C., I.A.D., S.C.H., and J.R.L. contributed equally to the work.

Reprints: Robert C. Rees, Department of Life Sciences, Nottingham Trent University, Clifton Lane., Nottingham NG11 8NS, United Kingdom; e-mail: robert.rees@ntu.ac.uk.

The publication costs of this article were defrayed in part by page charge payment. Therefore, and solely to indicate this fact, this article is hereby marked "advertisement" in accordance with 18 U.S.C. section 1734.

(C) 2001 by The American Society of Hematology 
between intracellular and cell surface expressed HLA-peptide complexes. It is therefore not known whether CML cells can express BCR-ABL-derived and thus leukemia-specific peptides on the cell surface in the context of HLA. Direct proof of this would provide powerful scientific support for the development of immunization strategies against BCR-ABL.

Mass spectrometry with nanospray ionization (NSI/MS) is a sensitive technique available for the identification of small quantities of biological molecules. Skipper et $\mathrm{al}^{22}$ used mass spectrometry to demonstrate that Melan A/MART 1 and gp100 HLA-A*0201restricted epitopes can be eluted from surface class I HLA molecules on cultured melanoma cell lines. However, the application of mass spectrometry to study HLA-associated peptides on the surface of tumor cells has been limited. In adapting mass spectrometry to study primary tumor cells, a potential problem is that the signatures of low-frequency tumor-specific peptides may be masked by those of other cell surface peptides, expressed on other HLA alleles. Furthermore, analysis is complicated by potential contamination by peptides/proteins from the intracellular compartments. To address this problem and using CML as a model, we have conceived a strategy that allows for the presentation and subsequent elution of peptides presented through a single HLA allele. In this instance, this is achieved by transfecting HLA-A*0301 into the HLA class I-negative CML cell line K562, which expresses b3a2 $B C R-A B L$ mRNA.

In this study, we present for the first time evidence for surface HLA-A*0301-restricted b3a2 peptide expression, both on HLAA*0301-transfected K562 cells and on CML cells from HLA$\mathrm{A}^{+} / \mathrm{b} 3 \mathrm{a} 2^{+}$patients. Sequencing results obtained by using tandem mass spectrometry confirmed the presence of the HLA-A*0301restricted peptide KQSSKALQR, with an identical signature on both transfected K562 and primary CML cells. We also show that these patients can mount a CTL response against the BCR-ABL junctional peptide expressed on their CML cells, and we report on the specificity of these CTLs. Furthermore, using tetramer staining, we demonstrate that HLA-A3-restricted peptide-specific T cells are detectable in the peripheral circulation of CML patients and that these $\mathrm{T}$ cells can be expanded specifically in vitro to provide increased levels of BCR-ABL-specific T cells.

\section{Patients, materials, and methods}

\section{Patient population}

Table 1 gives the clinical details of the 11 patients and controls included in the study, together with HLA assignments and $B C R-A B L$ transcript type.

Table 1. Details of study patients and HLA typing

\begin{tabular}{rccccc}
\hline Patient & Sex & Age $(\mathrm{y})$ & Disease & $\begin{array}{c}\text { Transcript } \\
\text { type }\end{array}$ & HLA-A type \\
\hline 1 & $\mathrm{~F}$ & 54 & $\mathrm{CML}$ & $\mathrm{b} 3 \mathrm{a} 2$ & $\mathrm{~A} 2 / \mathrm{A} 3$ \\
2 & $\mathrm{M}$ & 47 & $\mathrm{CML}$ & $\mathrm{b} 3 \mathrm{a} 2$ & $\mathrm{~A} 3 / \mathrm{A} 29$ \\
3 & $\mathrm{M}$ & 59 & $\mathrm{CML}$ & $\mathrm{b} 3 \mathrm{a} 2$ & $\mathrm{~A} 2 / \mathrm{A} 3$ \\
4 & $\mathrm{M}$ & 31 & $\mathrm{CML}$ & $\mathrm{b} 2 \mathrm{a} 2$ & $\mathrm{~A} 1 / \mathrm{A} 3$ \\
5 & $\mathrm{M}$ & 49 & $\mathrm{CML}$ & $\mathrm{b} 3 \mathrm{a} 2$ & $\mathrm{~A} 1 / \mathrm{A} 3$ \\
6 & $\mathrm{~F}$ & 50 & $\mathrm{CML}$ & $\mathrm{b} 3 \mathrm{a} 2$ & $\mathrm{~A} 1 / \mathrm{A} 31$ \\
7 & $\mathrm{M}$ & 63 & $\mathrm{CML}$ & $\mathrm{b} 2 \mathrm{a} 2$ & $\mathrm{~A} 23 / \mathrm{A} 31$ \\
8 & $\mathrm{M}$ & 39 & $\mathrm{CML}$ & $\mathrm{b} 3 \mathrm{a} 2$ & $\mathrm{~A} 2 / \mathrm{A} 24$ \\
9 & $\mathrm{~F}$ & 47 & $\mathrm{AML}$ & $\mathrm{N} / \mathrm{A}$ & $\mathrm{A} 2 /-$ \\
10 & $\mathrm{M}$ & 22 & Normal & $\mathrm{N} / \mathrm{A}$ & $\mathrm{A} 2 / \mathrm{A} 3$ \\
11 & $\mathrm{M}$ & 41 & Normal & $\mathrm{N} / \mathrm{A}$ & $\mathrm{A} 3 /-$ \\
\hline
\end{tabular}

CML, chronic myeloid leukemia; AML, acute myeloid leukemia; N/A, not applicable.
Six patients expressed the $\mathrm{b} 3 \mathrm{a} 2$ transcript and 2 patients the $\mathrm{b} 2 \mathrm{a} 2$ transcript The controls were one $B C R$ - $A B L$-negative acute myeloid leukemia (AML) patient and 2 healthy subjects. Five patients were positive for HLA$\mathrm{A}^{*} 0301$, and 2 patients were negative for HLA-A*0301 but were positive for $\mathrm{b} 3 \mathrm{a} 2$. The remaining case was negative for HLA-A*0301 and expressed the b2a2 transcript. All samples for HLA-associated peptide analysis were obtained at leukapheresis carried out for routine clinical indications at original diagnosis. Leukapheresis was carried out by using a Cobe Spectra (Cobe Laboratories, Quedgeley, Glos), programmed for maximal PBMC collection in accordance with the manufacturer's instructions.

\section{Cell lines and gene transfection}

Transfectant cell lines expressing the single HLA allele HLA-A0301 were created from the major histocompatibility complex (MHC) class I-negative CML cell line K562 that is positive for the b3a2 BCR-ABL transcript. K562 cells were cultured in RPMI 1640 medium containing $10 \%$ fetal calf serum (FCS) (BioWhittaker, Wokingham, United Kingdom), penicillin (100 $\mathrm{U} / \mathrm{mL})$, streptomycin $(100 \mu \mathrm{g} / \mathrm{mL})$, gentamicin $(50 \mu \mathrm{g} / \mathrm{mL})$, HEPES buffer $(10 \mathrm{mM})$, and L-glutamine $(2 \mathrm{mM})$ (Gibco Life Technologies, Paisley, Scotland). Cells were maintained at $37^{\circ} \mathrm{C}$ in $5 \% \mathrm{CO}_{2}$ in a humidified atmosphere. Briefly, the HLA-A*0301 allele was cloned into the expression vector $\mathrm{pBJneo}$ and transfected into the cells by electroporation. Following establishment of transfected cells in selective medium, expression of the transfected gene was verified by cell surface staining with the monoclonal antibody Gap-A3 specific for HLA-A*0301 followed by flow-activated cells sorter (FACS) analysis. The transfected cells were then cloned by limiting dilution to obtain cell lines expressing high levels of HLA-A*0301. Cells expressing higher levels of the transfected HLA allele were stained with the anti-HLA class I monoclonal antibody W6/32 and positively sorted for by FACS to further isolate transfectants with enhanced expression levels of HLA-A*0301. Transfected cell lines were maintained in RPMI 1640 selective medium containing G418 $1 \mathrm{mg} / \mathrm{mL}$ (Gibco). Control lines consisting of vector alone were also created. The transfectant cell lines were checked for the continued expression of the transfected HLA allele by FACS analysis at regular intervals.

\section{Synthetic peptide}

The BCR-ABL fusion peptide sequence KQSSKALQR has been previously described as binding to HLA-A*0301. ${ }^{4}$ This peptide was made by using an ABI synthesizer with F-moc chemistry and purified by HPLC to more than $90 \%$ purity, then confirmed by mass spectrometry. It was dissolved in $50 \%$ dimethyl sulfoxide before use in the refolding of the HLA-A*0301 molecule for tetramer preparation (see below).

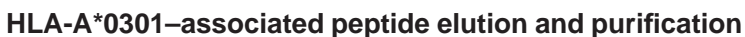

The acid elution technique was adapted from Storkus et al. ${ }^{23}$ The essential modifications were that prior to use, all plastic and glassware were treated in Sigmacote (Sigma, Poole, United Kingdom) to minimize peptide losses by surface adsorption. Citrate phosphate buffer $(0.131 \mathrm{M}$ citric acid and $0.066 \mathrm{M}$ sodium phosphate) was adjusted to $\mathrm{pH} 3.3$ by using $10 \mathrm{M} \mathrm{NaOH}$. A minimum of $10^{9}$ freshly leukapheresed CML cells or $5 \times 10^{8} \mathrm{~K} 562$ transfectants/controls were washed in serum-free RPMI medium and centrifuged at $1500 \mathrm{rpm}$ at $4^{\circ} \mathrm{C}$ for 5 minutes. Pelleted cells were resuspended in $20 \mathrm{~mL}$ citrate phosphate buffer for 5 minutes at room temperature and again centrifuged. The eluate-containing supernatant was collected and filtered through a $0.22-\mu \mathrm{m}$ micropore filter and stored at $-80^{\circ} \mathrm{C}$. Cellular integrity was assessed by using trypan blue, and the cells were found to be intact after citrate phosphate buffer elution.

Synthetic hepatitis B MHC class II-restricted peptide (TPPAYRPPNAPIL $_{128-140} 900 \mathrm{fmol}$ ) was added to the cell eluate before biochemical purification and separation, as an internal recovery standard. Trichloroacetic acid $(72 \% \mathrm{wt} / \mathrm{vol}, 2 \mathrm{~mL})$ was added, and the sample was placed in an ultrasonic bath for 10 minutes, centrifuged for 10 minutes at $4^{\circ} \mathrm{C}$ at $15000 \mathrm{~g}$, and followed by a further round of ultrasonication for 10 minutes. The supernatant was removed and applied to a cation exchange column (1 mL Econo S cartridge; BioRad, Hemel Hempstead, United Kingdom). The 
From www.bloodjournal.org at UCL Library Services on September 1, 2008. For personal use only.

column was washed with $0.1 \mathrm{M} \mathrm{HCl}(30 \mathrm{~mL})$, and the bound peptides were eluted with $0.1 \mathrm{M} \mathrm{NaOH}(25 \mathrm{~mL})$. The eluted peptide sample from the cation exchange column was brought to neutral $\mathrm{pH}$ with $2.8 \% \mathrm{vol} / \mathrm{vol}$ trifluoroacetic acid (TFA, $70 \mu \mathrm{L}$ ) and loaded via an injection loop onto an RP-HPLC precolumn $(1 \times 30 \mathrm{~mm}$ ODS; Jupiter, Phenomonex, Macclesfield, United Kingdom). The column was washed in solvent A (water containing $0.1 \% \mathrm{vol} / \mathrm{vol}$ TFA, $200 \mu \mathrm{L} / \mathrm{min}$ ) to remove any residual buffer or cation exchange salts. The solvent flow was then redirected via a 6-port switching valve (Rheodyne 7030) with $20 \%$ solvent B (acetonitrile containing $5 \% \mathrm{vol} / \mathrm{vol}$ glacial acetic acid and $0.01 \% \mathrm{vol} / \mathrm{vol} \mathrm{TFA}$ ) and $80 \%$ solvent C (water containing 5\% glacial acetic acid vol/vol and $0.01 \%$ TFA $\mathrm{vol} / \mathrm{vol}$ ) flowing through both the precolumn and the online analytical column used for peptide separation $(1 \times 150 \mathrm{~mm}$ ODS; Jupiter, Phenomonex). The columns were then subjected to an elution gradient of 20:80\% to 90:10\% solvent B:C (45 minutes, $20 \mu \mathrm{L} / \mathrm{min}$ ), and 3 to $5 \mu \mathrm{L}$ fractions were collected in silanized 1.1-mL tapered glass vials. To achieve low flow rates, a flow restrictor (microflow splitter; SGE, Milton Keynes, United Kingdom) was used with the HPLC pumps (ConstaMetric; Milton Roy, Wokingham, United Kingdom).

\section{Mass spectrometric analysis and peptide identification}

RP-HPLC fractions were analyzed by using an in-house constructed nano-electrospray ionization source interfaced to a quadruple ion trap mass spectrometry (Finnigan, Hemel Hempstead, United Kingdom). An Au/Pdcoated nano-electrospray tip (Nano-ES tip; Protana, Denmark) supported in a PTFE holder was attached to an adjustable platform, allowing movement along all 3 axes for the precise positioning of the tip near the heated capillary inlet of the mass spectrometer. The tip was gently broken against the heated capillary to initiate spraying and was maintained at a voltage of $1.1 \mathrm{kV}$ by connection to the instrumental high-voltage power supply.

Mass spectrometric conditions were as follows: heated capillary $100^{\circ} \mathrm{C}$, maximum injection time $400 \mathrm{~ms}$, total microscans 3 . The tube lens offset and heated capillary voltages were optimized for the doubly and triply protonated HLA-A*0301-associated peptide KQSSKALQR by running the synthetic peptide. The hepatitis B internal recovery standard peptide was isolated and analyzed to ensure that the level of recovery through the biochemical clean up was sufficient to allow mass spectrometric detection of natural peptides. Those peptides detected above the background noise were subjected to a zoom scan to ascertain their charge status. Ions found to be multiply charged in the mass range 300 to $800 \mathrm{Da}$ were subjected to collisionally activated dissociation with an isolation width of 3 arbitrary units, a relative collision energy of $30 \%$, and an automatic gain control at $1 \times 10^{9}$ to generate peptide sequence data.

\section{CTL assay}

Autologous T-cell blasts were used as APCs, prepared as previously described, ${ }^{16}$ using KQSSKALQR as the pulsing peptide. CTLs were generated by using a modification of the method of Plebanski et $\mathrm{al}^{24}$ and Norbury et al. ${ }^{16}$ On day 0 , PBMCs were plated out in 96-well U-bottomed plates at $37^{\circ} \mathrm{C}$ at $5 \% \mathrm{CO}_{2}$ at $10^{5} \mathrm{CD}^{+}$cells per well with autologous APCs $\left(10^{5}\right.$ per well) pulsed with peptide and $\beta 2$-microglobulin in Iscoves modified Dulbecco media (IMDM; Bio-Whittaker) with $10 \%$ heatinactivated $\mathrm{AB}$ serum. The medium contained $10 \mathrm{ng} / \mathrm{mL}$ interleukin-7 (IL-7; R\&D systems, Abingdon, United Kingdom). After 3 days an additional $25 \mu \mathrm{L}$ IMDM with AB serum and interleukin-2 (IL-2; First Link, West Midlands, United Kingdom) was added, to give a final IL-2 concentration of $10 \mathrm{IU} / \mathrm{mL}$.

A second and third stimulation with $10^{5}$ peptide-pulsed autologous APCs was performed on days 7 and 14 in the presence of $10 \mathrm{ng} / \mathrm{mL}$ IL-7. IL-2 was again added after 3 days to a final concentration of $20 \mathrm{IU} / \mathrm{mL}$. After 21 days of culture, individual wells containing the peptide-stimulated cells were assayed for peptide-specific CTL effector activity by using a standard ${ }^{51} \mathrm{Cr}$ release assay. ${ }^{16}$ Wherever possible, CTLs were also tested against autologous CML cells. Data on 84 wells were available for all cytotoxicity assays. Results are expressed as the percentage of wells with ${ }^{51} \mathrm{Cr}$ release more than $3 \mathrm{SDs}$ above the mean background ${ }^{51} \mathrm{Cr}$ release. ${ }^{16}$ The significance of differences in the percentages of positive wells between pairs of target cells (pulsed versus unpulsed) were tested by using Fisher exact test.

\section{Tetrameric MHC class I/peptide complexes}

The HLA-A*0301/KQSSKALQR tetramers were made as described previously. ${ }^{25}$ Briefly, the extracellular portion of the HLA-A*0301 coding DNA was amplified by polymerase chain reaction (PCR) and cloned into the pET $3 \mathrm{~d}$ vector (Novagen) modified by adding a C-terminal sequence coding for a biotinylation target. This system allows the HLA-A*0301 heavy chain to be expressed in bacteria and harvested as insoluble inclusion bodies. The $\beta 2$-microglobulin chain is produced in a similar fashion. Both molecules were solubilized in $8 \mathrm{M}$ urea before being added to the KQSSKALQR peptide in a dilution refolding under denaturing conditions. The refolded molecule was then purified by FPLC on a Superdex 75 column (Pharmacia, United Kingdom). Biotinylation was performed by using bacterially expressed Bir A enzyme, with comparable efficiency to commercially available Bir A (Avidity, Denver, CO). Monomeric biotinylated complexes were further purified by gel filtration followed by anion exchange chromatography. Tetrameric molecules were then formed by the addition of phycoerythrin-labeled streptavidin at a 4:1 molar ratio. The HLA-A2/ NLVPMVATV tetramer used for the controls shown in the central panels of Figure 2 was made in an analogous way.

\section{Tetramer analysis}

Freshly isolated PBMCs or cultured effector CTLs were resuspended in RPMI 1640 medium supplemented with $10 \%$ FCS and $5 \mathrm{mM} \mathrm{NaN3}$ to prevent internalization of the tetramers. Cells $\left(10^{6}\right)$ were stained with the HLA-A*0301/KQSSKALQR tetramer for 30 minutes at $37^{\circ} \mathrm{C}$. This staining was followed by a washing step and subsequent staining with fluorescein isothiocyanate-labeled anti-CD8 and peridinin chlorophyll protein-labeled anti-CD3 antibodies (Becton Dickinson, United Kingdom) for 30 minutes at $4{ }^{\circ} \mathrm{C}$. Cells were washed and fixed in RPMI with $1 \%$ paraformaldehyde and were analyzed within 24 hours. Data were acquired by using a FACScan flow cytometer using the CELLQuest software (Becton Dickinson). Identical methodology was used for the control HLA-A2/NLVPMVATV tetramer.

\section{mRNA transcript type}

The $B C R-A B L$ mRNA transcript type was determined by using minor modifications of our previously reported technique. ${ }^{26}$ Briefly, total RNA from PBMCs was extracted by using RNeasy Mini Kit (QIAGEN, Crawley, United Kingdom). After synthesis of complementary DNA (cDNA), $2 \mu \mathrm{L}$ was amplified by PCR using primers EK158 and EK159 as described previously. ${ }^{26}$

\section{Results}

Identification of HLA-A*0301-associated peptide KQSSKALQR

For each sample, the HPLC fractions found by NSI/MS to contain a triply charged ion corresponding to the HLA-A*0301-associated peptide KQSSKALQR (m/z 349.50) were subjected to tandem mass spectrometry (MS/MS). Figure 1A shows the resulting MS/MS product ion spectrum for a control cell eluate to which synthetic KQSSKALQR was added at a concentration of 2.3 $\mathrm{fmol} / \mu \mathrm{L}$. The ions resulting from the fragmentation of the parent ion of KQSSKALQR had been predicted, using MS Product within the Protein Prospector database (University of California at San Francisco). The observed fragment ions (as labeled in Figure 1) matched with the database prediction. The presence of KQSSKALQR peptide was also confirmed by inputting the observed fragment ion masses into MS-Tag tool, with the finding that the observed fragment ion masses were unique to KQSSKALQR.

Figure 1C shows the MS/MS spectrum for an eluate from K562 


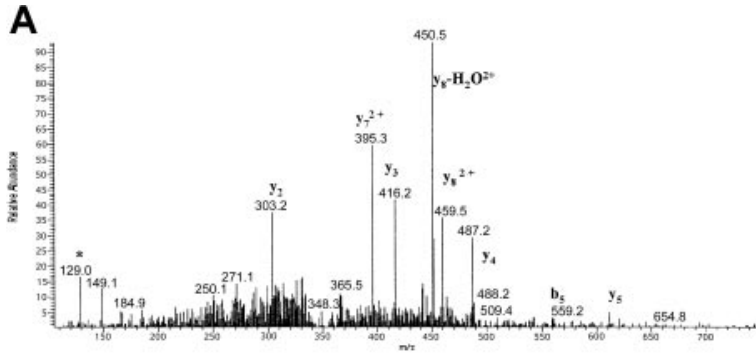

B
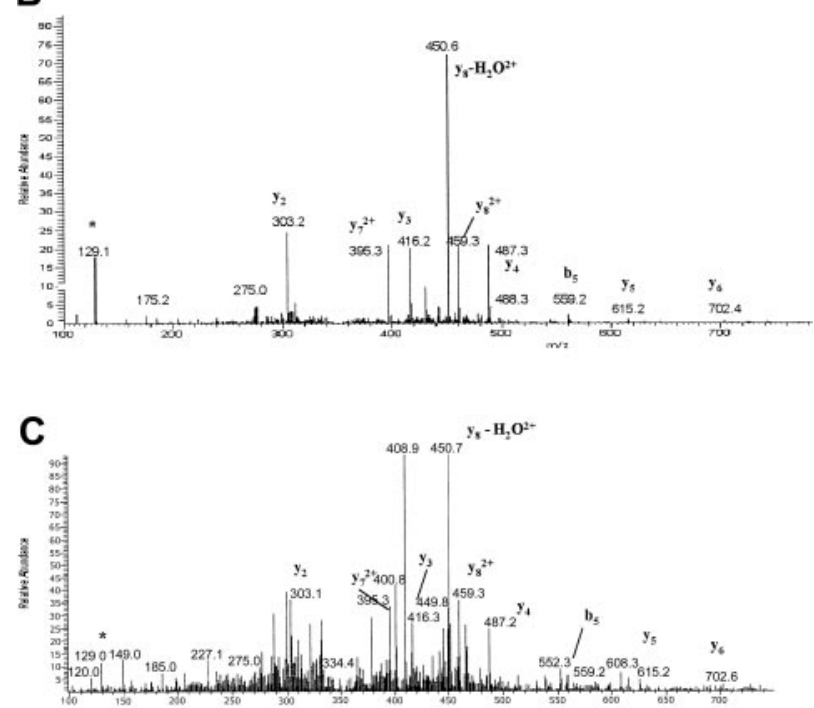

Figure 1. MS/MS spectra (precursor ion $\mathrm{m} / \mathbf{z}$ 349.5). (A) Synthetic KQSSKALQR peptide added to eluate from a control cell line. (B) Eluate from HLA-A*0301-positive primary CML cells (patient 1 in the tables). (C) Eluate from K562 cells transfected with HLA-A*0301. Relevant fragmentation ions are labeled. *denotes immonium ion.

cells transfected with HLA-A*0301. A close match was observed with the fragment ion profile for the synthetic peptide. In contrast, no fragment ions characteristic of KQSSKALQR (as labeled in Figure 1) were seen above the limit of detection in eluates from nontransfected K562 cells. The data therefore demonstrate that K562 cells expressing HLA-A*0301 as the only class I MHC molecule are able to present KQSSKALQR.
Mass spectrometric analysis was performed on 3 b3a2 BCR-ABL/HLA-A*0301-positive patients (cases 1-3) and one b3a2 BCR-ABL-positive/HLA-A*0301-negative patient (case 6). MS/MS product ion spectra characteristic of the KQSSKALQR peptide were found in eluates from the HLA$\mathrm{A} * 0301$-positive cases expressing the $\mathrm{b} 3 \mathrm{a} 2$ transcript. Figure $1 \mathrm{~B}$ shows the MS/MS spectrum obtained from an eluate from the HLA-A*0301-positive primary CML cells (patient 1 ) in which the fragment ion pattern matches that observed for the synthetic peptide, confirming the presence of KQSSKALQR. In contrast, no evidence of the KQSSKALQR peptide was found above the mass spectrometric limit of detection in the HLA-A*0301negative patient (case 6).

Tables of BCR-ABL-derived peptides able to bind to HLA-A*0301 were also predicted, using the computer algorithms BIMAS (http://www.bimas.dcrt.gov) and Syfpeithi (http:// www.uni-tuebingen.de/kxi). These data allowed us to confirm that our defined peptide would also be selected as a potential binding candidate by the 2 commonly used peptide prediction algorithms.

\section{CTL directed against BCR-ABL junctional peptides}

Seven CML patients (5 HLA-A*0301 positive and 2 HLA-A*0301 negative) and 2 HLA-A*0301-positive healthy subjects were studied for evidence of CTL against BCR-ABL junctional peptides, using autologous T-cell blasts pulsed with BCR-ABL peptides as APCs. All 7 CML patients had well-controlled chronic phase CML at the time of sampling. The results are shown in Table 2. Effector CTLs were grown from all 7 HLA-A*0301-positive subjects (5 CML patients and 2 healthy subjects), which were cytotoxic against autologous T-cell blasts expressing the HLA-A*0301-associated peptide KQSSKALQR. In all 7 HLA-A*0301-positive patients/ controls, sufficient effectors were available to show that these CTLs were also cytotoxic against allogeneic HLA-A*0301positive T-cell blasts pulsed with this peptide. Similarly, where sufficient CTL were available for study, these CTLs were also cytotoxic against unpulsed autologous and/or allogeneic HLAA*0301-positive CML cells, although not against HLA-mismatched CML cells. Effector CTLs were not grown from the 2 HLA-A*0301-negative CML patients (cases 7 and 8 in Table 2).

Table 2. Specificity of CTL generated with BCR-ABL peptide KQSSKALQR (\% positive wells against target cells)

\begin{tabular}{|c|c|c|c|c|c|c|c|}
\hline Patient & $\begin{array}{l}\text { Autologous } \\
\text { lymphoblasts } \\
\text { without } \\
\text { peptide }\end{array}$ & $\begin{array}{l}\text { Autologous } \\
\text { lymphoblasts } \\
\text { with peptide }\end{array}$ & $\begin{array}{l}\text { Matched } \\
\text { lymphoblasts } \\
\text { without } \\
\text { peptide }\end{array}$ & $\begin{array}{c}\text { Matched } \\
\text { lymphoblasts } \\
\text { with peptide }\end{array}$ & $\begin{array}{l}\text { Autologous } \\
\text { CML cells }\end{array}$ & $\begin{array}{l}\text { Matched } \\
\text { CML cells }\end{array}$ & $\begin{array}{l}\text { Mismatched } \\
\text { CML cells }\end{array}$ \\
\hline \multicolumn{8}{|c|}{ CML patients } \\
\hline \multicolumn{8}{|c|}{ HLA-A*0301 positive } \\
\hline 1 & 6 & 44 & 4 & 33 & 58 & 36 & 6 \\
\hline 2 & 4 & 51 & 2 & 27 & 27 & - & - \\
\hline 4 & 1 & 20 & 6 & 21 & - & - & 5 \\
\hline 5 & 5 & 30 & 7 & 19 & - & 26 & 6 \\
\hline \multicolumn{8}{|c|}{ HLA-A*0301 negative } \\
\hline 7 & 1 & 4 & 1 & 11 & - & 1 & - \\
\hline 8 & 5 & 3 & 4 & 7 & - & 6 & 7 \\
\hline \multicolumn{8}{|c|}{ Healthy subjects } \\
\hline 10 & 0 & 33 & 5 & 20 & $\mathrm{~N} / \mathrm{A}$ & 39 & 5 \\
\hline
\end{tabular}

Data are expressed as the percentage of wells with ${ }^{51} \mathrm{Cr}$ release $>3 \mathrm{SDs}$ above the mean background ${ }^{51} \mathrm{Cr}$ release. ${ }^{16}$ Percentages in bold were significantly different $(P<$ .001) from their respective control (Fisher exact test). CTL, cytotoxic T lymphocyte; CML, chronic myeloid leukemia; -, not done because of insufficient effector cells; N/A, not applicable. 
From www.bloodjournal.org at UCL Library Services on September 1, 2008. For personal use only.

Detection and expansion of peptide-specific peripheral blood T cells with HLA-A*0301 tetramers

The results of the studies using the HLA-A*0301/KQSSKALQR peptide tetramer are given in Figure 2 and summarized in Table 3. Of the 6 patients studied, 2 patients ( 1 and 2) who were positive for b3a2 and HLA-A*0301 demonstrated circulating $\mathrm{T}$ cells reactive with the HLA-A*0301/KQSSKALQR peptide tetramer (Figure 2, panels $1 \mathrm{~A}$ and 2A). Figure 2, panel 1C, demonstrates that stimulation with KQSSKALQR peptide (3 rounds) augmented tetramer-positive cells from $0.3 \%$ to $2.5 \%$. The remaining b3a2 and HLA-A*0301-positive patient (patient 3), showed negligible levels of tetramer-positive cells (Figure 2, panel 3A). However, after 1 round of stimulation with KQSSKALQR, tetramer-positive cells were detectable (Figure 2, panel 3C). This finding illustrates that there is potential to expand leukemia-reactive $\mathrm{T}$ cells in vitro and that tetramer staining may be helpful in monitoring their expansion. This correlates with our finding that on in vitro stimulation with peptide it was possible to raise CTLs with a similar reactivity pattern in each of patients 1, 2, and 3 (Table 2). Expanded CTLs were not screened with tetramers in patients 2 and 5 , as there were insufficient numbers of effector cells remaining after their use for specificity assays.

Patients 6 (b3a2-positive but HLA-A*0301-negative CML) and 9 (HLA-A*0301-negative AML) both showed no staining with the tetramer (Figure 2, panel 3A, 5A, and 6A). These cases serve as negative controls for tetramer staining. As further controls, each

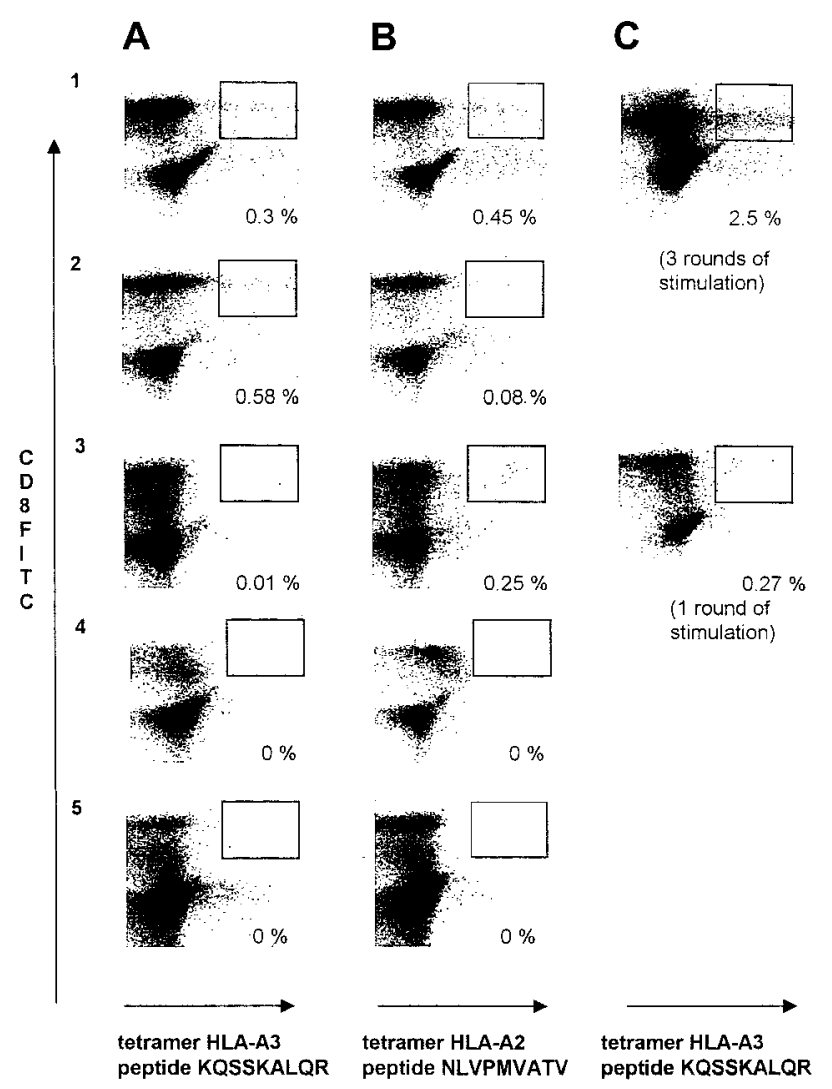

Figure 2. Tetramer staining of patients and peptide-expanded T-cell lines. Rows 1 to 5 refer to patients 1 to 3,6 , and 9 , respectively, in the Tables; for details see Results section. (A) Left-hand panels (1-5A) display the levels of tetramer-positive cells specific for HLA-A3 and peptide KQSSKALQR from the peripheral blood. (B) Central panels (1-5B) show the levels of tetramer-positive cells specific for HLA-A2 and the CMV peptide NLVPMVATV. (C) Right-hand panels $1 \mathrm{C}$ and $3 \mathrm{C}$ show the levels of tetramer-positive cells specific for HLA-A3 and the peptide KQSSKALQR from in vitro culture following peptide stimulation and expansion.

\begin{tabular}{cccc}
\multicolumn{4}{l}{ Table 3. Summary of mass spectrometry, CTL, and tetramer analysis } \\
\hline Patient & $\begin{array}{c}\text { Peptide } \\
\text { in eluate }\end{array}$ & $\begin{array}{c}\text { CTL } \\
\text { generated }\end{array}$ & Tetramer staining \\
\hline 1 & Positive & Positive & Positive \\
2 & Positive & Positive & Positive \\
3 & Positive & Positive & $\begin{array}{c}\text { Positive (after ex } \\
\text { vivo expansion) }\end{array}$ \\
& & Positive & Negative (ex vivo \\
5 & - & & expansion not \\
& & - & attempted) \\
6 & Negative & - & Negative \\
9 & N/A & - & Negative
\end{tabular}

Cases not studied by HLA-A3/KQSSKALQR tetramer are excluded. CTL, cytotoxic T lymphocytes; N/A, not applicable; - , not done.

patient was tested with tetramers of HLA-A2 with the HLA-A2associated CMV peptide NLVPMVATV (central panels of Figure 2). Both patients who were HLA-A2 negative (patients 2 and 3) are negative for this tetramer (Figure 2, panels 2B and 3B), even though patient 2 is CMV positive. Similarly, patient 3 is HLA-A2 positive and CMV positive and shows tetramer-positive cells (Figure 2, panel 3B).

\section{Discussion}

The present study addresses 2 issues of importance to our understanding of immune mechanisms in cancer, namely the presentation of HLA-restricted tumor-specific peptides and the host T-cell response to such peptides. We focus on the CML-specific BCR-ABL protein. First, using the strategy of a class I-negative CML cell line transfected with a single HLA allele together with NSI/MS, we show that the HLA-A*0301-associated peptide KQSSKALQR is presented by transfected but not by nontransfected K562 cells. This finding demonstrates that a CML cell line can process the $\mathrm{BCR}-\mathrm{ABL}$ fusion protein and can process and present peptides derived from the BCR-ABL junction on the cell surface in association with HLA class I antigen. The finding is in agreement with previous indirect evidence of HLA-associated BCR-ABL expression. ${ }^{16,27,28}$ We then extend this NSI/MS methodology to show that primary CML cells from b3a2/HLA-A*0301positive patients also express KQSSKALQR on the CML cell surface. To our knowledge this represents the first direct evidence that a hematologic malignancy can express leukemia-specific peptides on the cell surface, in association with HLA class I antigens, which has until now remained unconfirmed. Second, we show that these patients can mount an in vitro CTL response against the BCR-ABL junctional peptide expressed on their CML cells and that these CTLs are capable of killing autologous CML cells. We also demonstrate by tetramer staining that KQSSKALQRspecific $T$ cells are detectable in the peripheral circulation of these patients and that these $\mathrm{T}$ cells can be expanded specifically in vitro.

The demonstration that BCR-ABL junctional peptides can be eluted directly from CML cells is consistent with observations that appropriate synthetic 9-mer b3a2 peptides can bind HLAA*0301.4,7,8 None of the 9-mer b3a2 peptides "shifted" by a single amino acid in either $\mathrm{N}$ - or $\mathrm{C}$-terminal directions from KQSSKALQR were detected in the eluates. This finding is strong evidence that the defined HLA-binding peptide was not derived from nonspecific proteolysis but was processed and presented in association with class I HLA at the surface of CML cells. Neither of these shifted 9-mers were predicted to bind with high affinity to either HLAA*0301 or to other class I HLA molecules expressed by the 
From www.bloodjournal.org at UCL Library Services on September 1, 2008. For personal use only.

patients. An eluate from a b3a2-positive HLA-A*0301-negative patient lacked the KQSSKALQR peptide, and this finding further supports the view that this peptide was derived from endogenously processed $\mathrm{BCR}-\mathrm{ABL}$ protein presented in the HLA peptide binding groove in HLA-A*0301-positive CML cells.

Although we demonstrate that both BCR-ABL antigen presentation and CTL response are intact in CML, these mechanisms cannot operate optimally in vivo, otherwise the disease would never come to clinical attention. The $\mathrm{Ph}$-positive-initiating cell may not express BCR-ABL and may therefore escape immunologic detection. However, $B C R-A B L$ transcripts have been detected in healthy subjects, using a sensitive reverse transcriptase-PCR assay, ${ }^{29}$ and both $\mathrm{CTL}$ and $\mathrm{CD} 4^{+}$proliferative responses against BCR-ABL can be elicited in healthy subjects. ${ }^{5,6,8,9-16} \mathrm{CML}$ may rarely spontaneously regress. ${ }^{30-32}$ It is therefore interesting to speculate that certain CML clones may present suitably immunogenic peptides, which become targets for CTL. CML may be less common in HLA-A3positive or B8-positive individuals, ${ }^{33}$ suggesting that peptide immunogenicity may differ according to HLA type. It is plausible that the BCR-ABL rearrangement may be more common than the prevalence of CML, but that a T-cell response may control or eliminate a BCR-ABL-positive clone. Recent data suggest that a T-cell response against proteinase 3, a granule protein overexpressed in CML cells, may be important in clearing leukemic cells after therapy. ${ }^{34}$ Thus, CML may come to clinical attention as a result of an immune tolerance or anergy to BCR-ABL, as well as the occurrence of the $B C R-A B L$ rearrangement per se.

CTL precursors capable of being activated in vitro to kill autologous tumor cells have been described in malignant melanoma. ${ }^{35}$ However, melanoma-associated antigens (MAGEs) are mostly unmutated self-antigens, such as MAGE1-3 or tyrosinase. ${ }^{36}$ A completely novel tumor-specific antigen such as BCR-ABL would be less likely to induce tolerance or anergy than a normal self-antigen. However, there are a number of possible explanations for the failure of BCR-ABL to induce effective CTL in vivo in
CML patients. These explanations include low T-cell receptor avidity or weak antigen expression or T-cell tolerance in patients with a massive leukemic burden. ${ }^{37}$ Dendritic cells from CML patients are part of the leukemic clone, ${ }^{28}$ and, hence, there is the potential for induction of T-cell tolerance to BCR-ABL via endogenous expression by thymic dendritic cells. Specific $\mathrm{CD}^{+}$ $\mathrm{T}$ cells, which are thought to be essential for most $\mathrm{CD} 8^{+} \mathrm{T}$-cell responses, ${ }^{38}$ may be absent or anergic. It is notable that $\mathrm{CD}^{+}$ $\mathrm{T}$ cells specific for $\mathrm{b} 3 \mathrm{a} 2$ peptide could be detected in healthy donors but not in CML patients. ${ }^{13}$ The requirement for specific $\mathrm{CD} 4{ }^{+}$ $\mathrm{T}$ cells in generating b3a2-specific CTL may be circumvented during in vitro CTL assays by the use of IL-2 and IL-7.

The potential promise of peptide vaccination for the therapy of malignant disease has yet to be realized. This may, in part, be due to difficulties in accurately defining tumor-specific peptides. The present strategy of using a single HLA-transfected cell line together with mass spectrometry demonstrates a novel approach for precise definition of HLA-associated peptides. This strategy may be widely applicable in many other malignant and nonmalignant disease states. The data support the view that immunization strategies against BCR-ABL may be helpful in boosting T-cell responses in CML. A recent preliminary report suggests that some CML patients may generate specific proliferative immune responses following vaccination with BCR-ABL junctional peptides, ${ }^{37}$ although CTL responses were not observed in that study. The present findings give encouragement to further studies to define the optimal composition, route, and timing of administration of immunization with BCR-ABL junctional peptides.

In summary, the present data provide the first direct evidence that CML cells express surface BCR-ABL junctional peptides in association with HLA class I, and that antigen-specific T cells can target these peptides. CML can, therefore, be added to the list of examples of human tumors known to express a tumor-restricted peptide in the context of HLA.

\section{References}

1. Groffen J, Stephenson JR, Heisterkamp N, de Klein A, Bartram CR, Grosveld G. Philadelphia chromosome breakpoints are clustered within a limited region, bcr, on chromosome 22. Cell. 1984;36:93-99.

2. Kurzrock R, Guttermann JU, Talpaz M. The molecular genetics of Philadelphia chromosomepositive leukaemias. N Engl J Med. 1988;319: 990-998.

3. McLaughlin J, Chianese E, Witte ON. In vitro transformation of immature hematopoietic cells by the p210 bcr/abl oncogene product of the Philadelphia chromosome. Proc Natl Acad Sci U S A. 1987;84:6558-6562.

4. Bocchia M, Wentworth PA, Southwood S, et al. Specific binding of leukemia oncogene fusion protein peptides to HLA Class I molecules. Blood. 1995;85:2680-2684.

5. Bocchia M, Korontsvit T, Xu Q, et al. Specific human cellular immunity to bcr-abl oncogene-derived peptides. Blood. 1996;87:3587-3592.

6. Yotnda P, Firat P, Garcia-Pons F, et al. Cytotoxic T-cell response against the chimeric p210 BCR$A B L$ protein in patients with chronic myelogenous leukemia. J Clin Invest. 1998;101:2290-2296.

7. Buzyn A, Ostankovitch M, Zerbib A, et al. Peptides derived from the whole sequence of BCR$A B L$ bind to several class I molecules allowing specific induction of human cytotoxic T lymphocytes. Eur J Immunol. 1997;27:2066-2072.

8. Berke Z, Andersen MH, Pedersen M, Fugger L, Zeuthen J, Haurum JS. Peptides spanning the junctional region of both the abl/bcr and the bcr/ abl fusion proteins bind common HLA class I molecules. Leukemia. 2000;14:419-426.

9. Barrett J, Guimaraes A, Cullis J, Goldman JM. Immunological characterisation of the tumour specific bcr/abl junction of Philadelphia chromosome positive chronic myeloid leukaemia. Stem Cells. 1993;11(suppl 3):104-108.

10. ten Bosch GJA, Toornvliet AC, Friede T, Melief CJM, Leeksma OC. Recognition of peptides corresponding to the joining region of $\mathrm{p} 210^{\mathrm{BCR}-\mathrm{ABL}}$ protein by human T cells. Leukemia. 1995;9: 1344-1348.

11. ten Bosch GJA, Joosten AM, Kessler JH, Melie CJM, Leeksma OC. Recognition of BCR-ABL positive leukemic blasts by human $\mathrm{CD} 4^{+} \mathrm{T}$ cells elicited by primary in vitro immunization with a BCR-ABL breakpoint peptide. Blood. 1996;88: 3522-3527.

12. Macintyre AR, Christmas SE, Clark RE. The influence of class II HLA type on the lymphoproliferative response of normal donors to a bcr-abl fusion peptide. Exp Hematol. 1996;24:1307-1311.

13. Pawelec G, Max H, Halder T, et al. BCR/ABL leukaemia oncogene fusion peptides selectively bind to certain HLA-DR alleles and can be recognised by $T$ cells found at low frequency in the repertoire of normal donors. Blood. 1996;88:2118-2124.

14. Mannering SI, McKenzie JL, Fearnley DB, Hart DNJ. HLA-DR1 restricted bcr-abl (b3a2) specific CD4 ${ }^{+}$T lymphocytes respond to dendritic cells pulsed with b3a2 peptide and antigen-presenting cells exposed to b3a2 containing cell lysates. Blood. 1997;90:290-297.

15. Yasukawa M, Ohminami H, Kaneko S, et al. $\mathrm{CD}^{+}{ }^{+}$cytotoxic T-cell clones specific for bcr-abl b3a2 fusion peptide augment colony formation by chronic myelogenous leukemia cells in a b3a2specific and HLA-DR restricted manner. Blood. 1998;92:3355-3361.

16. Norbury LC, Clark RE, Christmas SE. b3a2 BCR$A B L$ fusion peptides as targets for cytotoxic $T$ cells in chronic myeloid leukaemia. $\mathrm{Br} \mathrm{J}$ Haematol. 2000;109:616-621.

17. Papadopoulos KP, Suciu-Foca N, Hesdorffer CS, Tugulea S, Maffei A, Harris PE. Naturally processed tissue and differentiation stage-specific autologous peptides bound by HLA Class I and II molecules of chronic myeloid leukaemia blasts. Blood. 1997;90:4938-4946.

18. Bellone M, lezzi G, Manfredi AA, et al. In vitro priming of cytotoxic $T$ lymphocytes against poorly immunogenic epitopes by engineered antigen presenting cells. Eur J Immunol. 1994;24:26912698.

19. Celluzzi C. Peptide pulsed dendritic cells induce antigen specific CTL mediated protective tumour immunity. J Exp Med. 1996;183:283-287.

20. Protti MP, Imro MA, Manfredi AA, Consogno G, Bellone M, Rugarli C. Particulate naturally processed peptides prime a cytotoxic response against human melanoma in vitro. Cancer Res. 1996;56:1210-1213. 
21. Nair SK, Boczkowski D, Snyder D, Gilboa E. Antigen presenting cells pulsed with unfractionated tumour-derived peptides are potent tumour vaccines. Eur J Immunol. 1997;27:589-597.

22. Skipper JCA, Gulden PH, Hendrickson RC, et al. Mass spectrometric evaluation of HLA-A0201 associated peptides identifies dominant naturally processed forms of CTL epitopes from MART-1 and gp100. Int J Cancer. 1999;82:669-677.

23. Storkus WJ, Zeh HJ, Salter RD, Lotze MT. Identification of $T$ cell epitopes: rapid isolation of class I-presented peptides from viable cells by mild acid elution. J Immunother. 1993;14:94-103.

24. Plebanski M, Allsopp CE, Aidoo M, Reyburn H, Hill AV. Induction of peptide-specific primary cytotoxic T lymphocyte responses from human peripheral blood. Eur J Immunol. 1995;25:17831787.

25. Altman JD, Moss PAH, Goulder PJR, et al. Phenotypic analysis of antigen-specific T lymphocytes. Science. 1996;274:94-96

26. Broughton CM, Sherrington P, Pender N, Tidd DM, Clark RE. Molecular status of individual CFU-GM colonies derived from chemotherapymobilised peripheral blood stem cells in chronic myeloid leukaemia. Genes Chromosomes Cancer. 1997;18:292-298.

27. Nieda M, Nicol A, Kikuchi A, et al. Dendritic cells stimulate the expansion of bcr-abl specific CD8 $T$ cells with cytotoxic activity against leukaemic cells from patients with chronic myeloid leukaemia. Blood. 1998;91:977-983.

28. Choudhury A, Gajewski JL, Liang JC, et al. Use of leukaemic dendritic cells for the generation of antileukemic cellular cytotoxicity against Philadelphia chromosome-positive chronic myelogenous leukaemia. Blood. 1997;89:1133-1142.

29. Biernaux C, Loos M, Sels A, Huez G, Stryckmans P. Detection of major bcr-abl gene expression at a very low level in blood cells of some healthy individuals. Blood. 1995;86:3118-3122.

30. Fegan C, Morgan G, Whittaker JA. Spontaneous remission in a patient with chronic myeloid leukaemia. Br J Haematol. 1989;72:594-595.

31. Provan AB, Majer RV, Herbert A, Smith AG Spontaneous remission of chronic myeloid leukaemia with loss of the Philadelphia chromosome. Br J Haematol. 1991;78:578-579.

32. Musashi M, Abe S, Yamada T, et al. Spontaneous remission in a patient with chronic myelogenous leukemia. N Engl J Med. 1997;336:337-339.
33. Posthuma EFM, Falkenburg JHF, Apperley JF, et al. HLA-B8 and HLA-A3 coexpressed with HLA-B8 are associated with a reduced risk of the development of chronic myeloid leukaemia. Blood. 1999;93:3863-3865.

34. Molldrem JJ, Lee PP, Wang C, et al. Evidence that specific T lymphocytes may participate in the elimination of chronic myelogenous leukaemia. Nat Med. 2000;6:1018-1023.

35. van Pel A, van der Bruggen P, Coulie PG, et al. Genes coding for tumor antigens recognized by cytolytic T lymphocytes. Immunol Rev. 1995;145: 229-250.

36. Marchand M, van Baren N, Weynants P, et al Tumor regressions observed in patients with metastatic melanoma treated with an antigenic peptide encoded by gene MAGE-3 and presented by HLA-A1. Int J Cancer. 1999;80:219-230.

37. Pinilla-lbarz J, Cathcart K, Korontsvit T, et al. Vaccination of patients with chronic myelogenous leukaemia with bcr-abl oncogene breakpoint fusion peptides generates specific immune responses. Blood. 2000;95:1781-1787.

38. Clarke SR. The critical role of CD40/CD40L in the CD4-dependent generation of $\mathrm{CD}^{+}{ }^{+} \mathrm{T}$ cell immunity. J Leuk Biol. 2000;67:607-614. 